\title{
El libro álbum en la producción editorial peruana ${ }^{1}$
}

\author{
Daniela Alcalde Flores
}

\section{LA LITERATURA INFANTIL Y JUVENIL: UN SECTOR EN CRECIMIENTO}

Los últimos quince años han sido fundamentales para el crecimiento de la industria editorial y la literatura infantil y juvenil (LIJ) en el Perú. Décadas atrás, si bien se puede destacar la obra de notables autores como Francisco Izquierdo Ríos, Carlota Carvallo y Rosa Cerna Guardia, también cabe señalar que las condiciones para la difusión de la LIJ no fueron las más favorables. Como sostiene el investigador chileno Manuel Peña (2009): "Perú es uno de los países latinoamericanos con mayores problemas socioeconómicos, lo que ha influido en el lento desarrollo de la literatura infantil. Hasta los años ochenta, las ediciones eran convencionales, modestas y con problemas de distribución" (p. 597).

Sobre las décadas siguientes, Jorge Eslava (2009) destaca el rol de las editoriales extranjeras:

Las grandes editoriales que trabajan en el Perú desde hace décadas, específicamente Santillana y Norma, iniciaron sus planes de lectura asociados a la promoción y venta de manuales escolares. Es decir, la campaña en favor de la lectura de niños y jóvenes nacía en el Perú no como una preocupación del Estado ni de la sociedad civil, sino gracias al empeño de unas empresas con indudable experiencia en ese terreno, y desde luego con mucha expectativa comercial. (p. 5)

Sin embargo, el nuevo siglo trajo consigo dos políticas estatales que han impulsado el crecimiento del sector editorial y de la literatura infantil y juvenil. La primera es la Ley de Democratización del Libro y de Fomento de la Lectura (2003), que establece algunos beneficios para las editoriales nacionales y los importadores de libros, tales como la exoneración del impuesto general a las ventas (IGV) y el reintegro tributario por la adquisición de bienes o insumos para proyectos editoriales. La segunda es la implementación del plan lector como estrategia para promover la lectura entre los estudiantes de la educación básica regular, según la cual los estudiantes deben leer doce libros durante el año. Esto, sin duda, ha incrementado la demanda de libros infantiles y juveniles en la escuela.

1 La versión original de este artículo fue realizada como trabajo final del Máster en Libros y Literatura Infantil y Juvenil organizado por la Universitat Autònoma de Barcelona y el Banco del Libro de Venezuela. 
Con la prorrogación de los beneficios tributarios de la ley del libro hasta el 2018, "todo indica que la producción editorial de literatura infantil y juvenil (LIJ) en el Perú seguirá fortaleciéndose en los próximos años como lo ha venido haciendo desde hace una década" (Rodríguez, 2015, p. 249).

\section{¿Y EL LIBRO ÁLBUM?}

En este contexto de crecimiento del sector editorial y de la LIJ en el Perú, conviene preguntarse qué lugar ocupa el libro álbum, un tipo de publicación que ha generado mucho interés entre autores, editoriales y académicos, principalmente desde los años sesenta. Incluso se considera que "es la única contribución que la literatura infantil ha hecho a la literatura, [y] los demás géneros son puramente imitativos" (Hunt citado por Silva-Díaz, 2005, p. 30).

Si bien su desarrollo en Latinoamérica ha sido posterior, el libro álbum se encuentra posicionado en varios países de la región, aunque en el Perú su producción es aún incipiente. No obstante, cabe destacar que los últimos cinco años han sido particularmente favorables. A continuación, se mencionan cuatro momentos importantes en este período:

1. En el 2010, inició sus actividades Polifonía Editora, único sello editorial peruano dedicado a la publicación de libros álbum.

2. En el 2013, las autoras Micaela Chirif e Issa Watanabe ganaron el XVII Concurso de Álbum Ilustrado "A la orilla del viento" con ¡Más te vale, mastodonte!

3. En el 2014, Desayuno, libro álbum de Micaela Chirif y Gabriel Alayza, fue seleccionado en el prestigioso catálogo The White Ravens.

4. En el 2015, el Ministerio de Educación (Minedu) solicitó por medio de las licitaciones públicas n. ${ }^{\circ}$ 011-2015 y n.o 016-2015 la compra de libros álbum para la implementación de bibliotecas de aula a nivel nacional.

Este último punto resulta muy importante, pues las licitaciones del Minedu generan gran expectativa entre las editoriales, dado el volumen de compra que representan. Ante ello, se considera oportuno analizar nuestra producción editorial para identificar si existen libros álbum de autores peruanos que puedan responder a esta nueva demanda e identificar algunas de sus características. Es esta la línea que pretende seguir la presente investigación.

Con este propósito, se abordó el período 2013-2105, tres años muy significativos por las razones antes expuestas. Debido a la imprecisión en el registro ISBN de varios libros que no figuran como infantiles, a pesar de serlo, y a la consecuente dificultad de tener un listado certero de las publicaciones infantiles a nivel nacional, para efectos de esta 
investigación se revisaron los catálogos de las editoriales que destacan por su posicionamiento en el mercado (Santillana, Norma, SM y Ediciones Lexicom), o por un mayor acercamiento al libro álbum o al libro ilustrado (Polifonía Editora, Graph Ediciones, Fondo de Cultura Económica y el Museo de Arte de Lima)², y se aplicaron los siguientes criterios para delimitar el corpus:

1. Autores de nacionalidad peruana

2. Año de publicación correspondiente al período de estudio, según registro ISBN

3. Libros publicados en primera edición

4. Número de páginas menor de 40

5. Ilustración en todas las dobles páginas

6. Cantidad de líneas por binaria menor o igual a 10

Tras este proceso, quedaron 31 libros en el corpus, los cuales fueron analizados uno por uno con ayuda de una ficha de observación. Esta tenía como objetivo identificar cómo se manifestaba en las lecturas del corpus cada una de las categorías de análisis: narratividad, relación texto-imagen, puesta en página, uso de las páginas, secuenciación de las imágenes, uso narrativo de los peritextos, uso narrativo de los elementos gráficos del libro, uso narrativo del soporte, personajes, tiempo, escenario, lógica espacial, brechas de interpretación y presencia de ícono-textos.

Luego se procedió a contrastar la información obtenida con una ficha de análisis por categorías, la cual permitió obtener valores cuantitativos sobre la frecuencia de los indicadores respectivos y conclusiones cualitativas sobre tendencias en el uso de los recursos observados. Por último, se empleó una ficha de clasificación para identificar qué libros del corpus tenían mayor cercanía con el lenguaje del libro álbum.

\section{EL UNIVERSO DEL LIBRO ÁLBUM}

Entre las múltiples definiciones existentes, para efectos de este trabajo se utilizará la que propone Sophie Van der Linden en su obra Lire l'album (2006):

El álbum sería una forma de expresión que presenta una interacción entre textos (que pueden ser subyacentes) e imágenes (especialmente preponderantes) en el seno de un soporte libro, caracterizado por su libre organización de la doble página, la diversidad de sus realizaciones materiales y la sucesión fluida y coherente de sus páginas. (Citado por Bosch, 2007, p. 35)

2 Sellos como Alfaguara, Panamericana Editorial y Editorial San Marcos quedaron fuera del estudio, debido a que no tenían publicaciones como las requeridas en el período seleccionado. 
En las licitaciones mencionadas, no hay claridad en la definición de libro álbum por parte del Minedu. Mientras que la licitación n..$^{\circ}$ 011-2015 hace énfasis en que el texto no puede comprenderse sin las imágenes, en la n. ${ }^{\circ}$ 016-2015 se simplifica esta relación a un diálogo entre texto e imagen, al cual añade un elemento más: el soporte. En esta última, también se aprecia la imprecisión de clasificar al libro álbum como un tipo de cuento contemporáneo caracterizado por el hecho de que el escritor es quien ilustra el cuento.

Ante la definición de Van der Linden y las que ofrece el Minedu, cabe precisar que si bien el libro álbum tiene muchas posibilidades de realización, con el tiempo ha desarrollado un lenguaje propio que se caracteriza por ciertos usos distintivos de los cuales dispone de manera flexible, alternativa y eventual durante la narración. Entre estos se observa que el texto difícilmente se puede leer solo, la relación texto-imagen suele ir más allá de la amplificación ${ }^{3}$, el uso narrativo del soporte, los peritextos ${ }^{4} \mathrm{y}$ los elementos gráficos del libro. También incluyen el uso predominante de la doble página, una articulación media entre imágenes que permite seguir una lógica espacial y de personajes, así como la presencia de brechas de una página a otra, que tienen fines narrativos como otorgar ritmo, suspenso, etcétera. Dado el peso narrativo de la imagen, también se puede observar que en ella recae la representación de personajes, el escenario y el paso del tiempo, además de presentar ícono-textos ${ }^{5}$ con función narrativa.

Esta investigación busca identificar los libros álbum que usan frecuentemente este lenguaje para narrar, los que lo emplean ocasionalmente y aquellos que son más cercanos al libro ilustrado, donde las imágenes suelen estar aisladas o poco articuladas, cumplen la función tradicional de amplificación y las brechas entre ellas recurren a la imaginación del lector y al texto para llenar los vacíos narrativos. Para ello, se establecieron 13 categorías de observación a partir de las características antes mencionadas: narratividad, relación texto-imagen, puesta en página, uso de las páginas, secuenciación de las imágenes, uso narrativo de los peritextos, los elementos gráficos y el soporte, personajes, tiempo, escenarios, lógica espacial, brechas de interpretación e ícono-textos. Los indicadores de cada una abarcan tanto lo frecuente en el libro ilustrado como en el libro álbum.

Considerando los intereses de las licitaciones mencionadas, se comentarán los libros que emplean los recursos propios del lenguaje del libro álbum mayoritaria y ocasionalmente, de manera que resultan innovadores entre la producción local, la cual está más familiarizada con el libro ilustrado.

3 Se propone este término para referirse a aquella relación en la que texto e imagen sostienen un discurso similar que sigue en la misma dirección, generalmente determinada por el texto. La ilustración añade información al texto y viceversa.

4 Los peritextos son aquellos elementos que acompañan al texto y forman parte del libro, tales como la tapa, contratapa, guardas, portada, índice, etcétera.

5 Los ícono-textos son los textos que se encuentran como parte del mundo representado en la ilustración. 


\section{EL LENGUAJE DEL LIBRO ÁLBUM: UN EXTRAÑO EN LA PRODUCCIÓN EDITORIAL PERUANA}

En la muestra analizada, se encontró que solo cuatro de las publicaciones (el 12,9 \% de la muestra total de 31 libros) emplean el lenguaje propio del libro álbum. A continuación, se comentará este uso en cada uno de ellos.

\section{Desayuno (Polifonía Editora, 2013)}

Con textos de Micaela Chirif e ilustraciones de Gabriel Alayza, nos muestra a una abuela que prepara el desayuno para su nieto en una apacible casa de playa. Mientras lo hace, muchos seres fantásticos aparecen en su cocina para darle un matiz divertido a tan cotidiana labor. Entre los libros observados, es el que presentó mayor variedad en el uso de los recursos.

En cuanto a la narratividad, las imágenes interactúan con el texto para narrar y también lo hacen solas en un momento muy importante de la historia: cuando la abuela baila con el buzo llegando al punto más elevado del desborde de su fantasía. Asimismo, presenta variedad en la puesta en página, alternando entre la asociación, la disociación y los espacios compartimentados ${ }^{6}$. En cuanto a la relación texto-imagen, principalmente se observa la disyunción ${ }^{7}$ que produce la ironía entre lo cotidiano y sencillo que se dice en los textos y las situaciones fantásticas y divertidas que muestran las imágenes (figura 1).

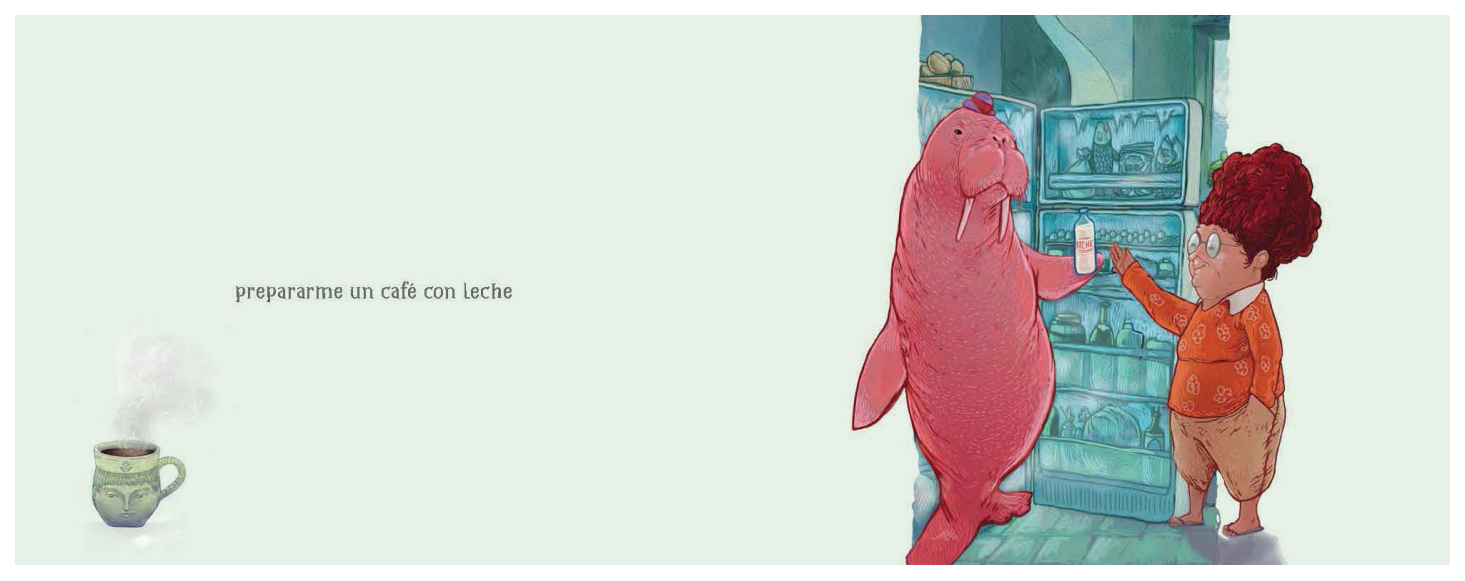

Figura 1

6 La asociación se presenta cuando el texto y la imagen están en páginas separadas. La disociación, cuando el texto y la imagen comparten espacio en la página. En el caso de los espacios compartimentados, se divide el espacio de la página en varias viñetas cuyos límites pueden ser invisibles. Estos términos han sido propuestos por Sophie Van der Linden (Colomer, 2010, 2017).

7 Según Van der Linden (2015), se produce cuando “texto e imagen sostienen un discurso autónomo porque se contradicen o porque desarrollan narraciones paralelas" (p. 17). 
También debe destacarse que alterna entre las imágenes articuladas y altamente articuladas para variar el ritmo de la narración. En este caso, invita al lector a detenerse en cada paso de esa maravillosa secuencia de baile entre la abuela y el buzo, en la cual también se aprovecha al máximo el soporte del libro y el formato apaisado (figura 2).
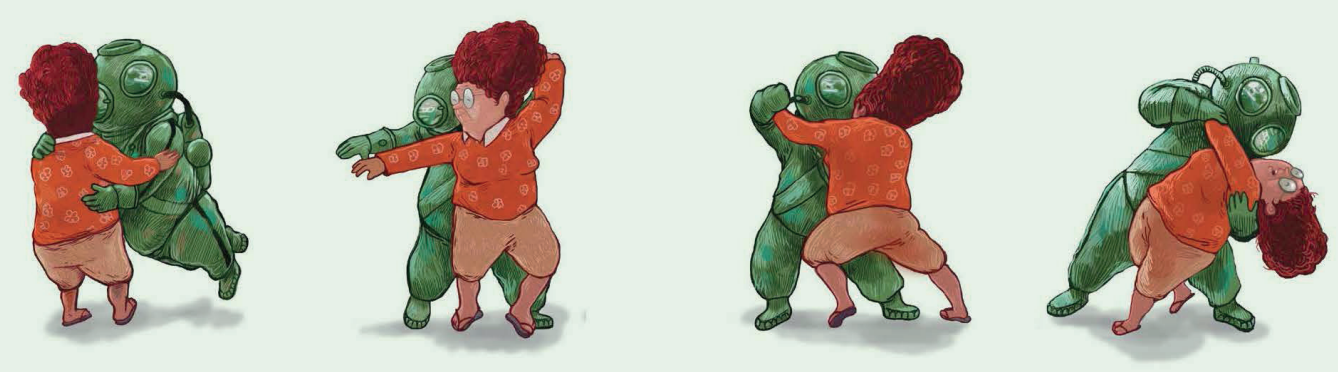

Figura 2

Desayuno es un excelente ejemplo de que todos los elementos del libro álbum pueden tener un sentido y estar al servicio de la narración (figura 3). Así, la contratapa amplía la historia, el color verdoso del fondo de las páginas se asocia con el mar, un cambio en la tipografía introduce la voz del nieto que marca el retorno de la abuela a la realidad y el uso de los márgenes permite diferenciar entre la realidad de la fantasía. Además, la distribución de los elementos sigue una lógica espacial (el elemento novedoso casi siempre aparece por la derecha) y existen brechas de interpretación, ya que no se aclara qué ocurre con cada uno de los personajes con los que interactúa la abuela o qué hace ella entre escenas.

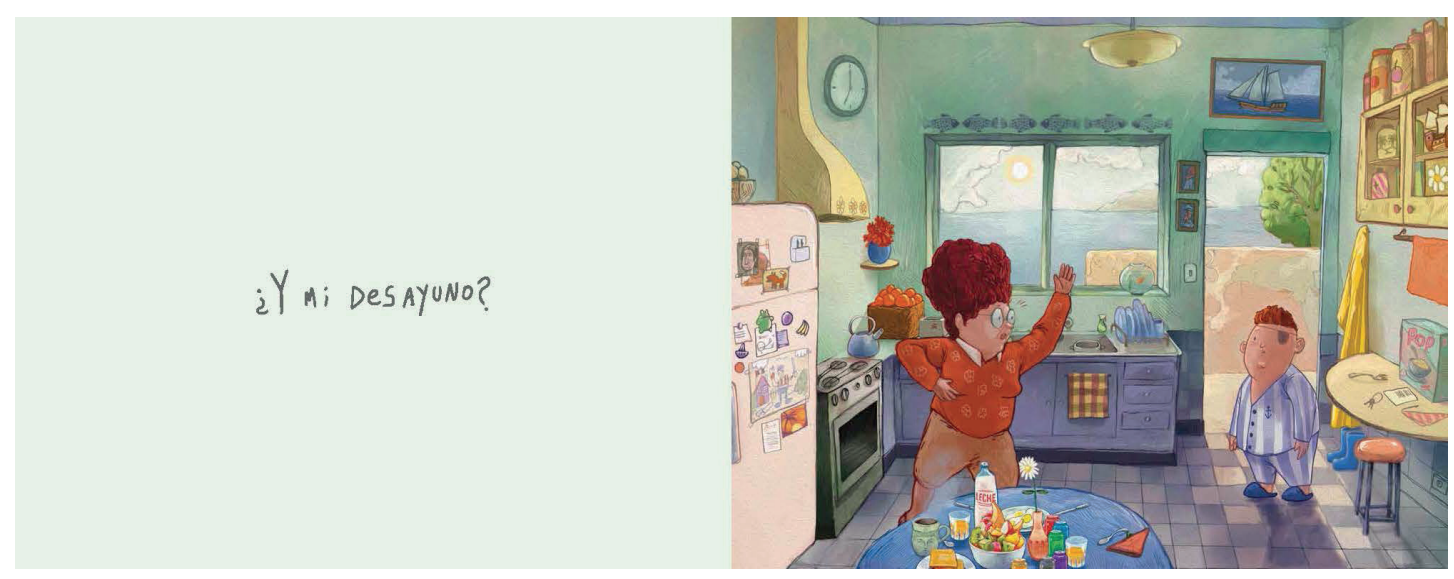

Figura 3 
¡Más te vale, mastodonte! (Fondo de Cultura Económica, 2014)

Con textos de Micaela Chirif e ilustraciones de Issa Watanabe, nos muestra a un niño que trata de domesticar a un mastodonte que se niega a seguir sus indicaciones $y$, cuando lo hace, solo genera destrozos. A pesar de todo, existe un fuerte lazo afectivo entre ambos.

Al igual que en Desayuno, se narra por medio de la interacción entre texto e imagen con una puesta en página disociada y la imagen narra sola un momento importante: cuando el niño se queda dormido y se aprecia el cariño que le tiene el mastodonte. Para ello, se emplean los espacios compartimentados y se aprovecha el soporte del libro. La relación texto-imagen alterna entre la amplificación (predominante) y la complementariedad $^{8}$ que se muestra al final (figura 4).

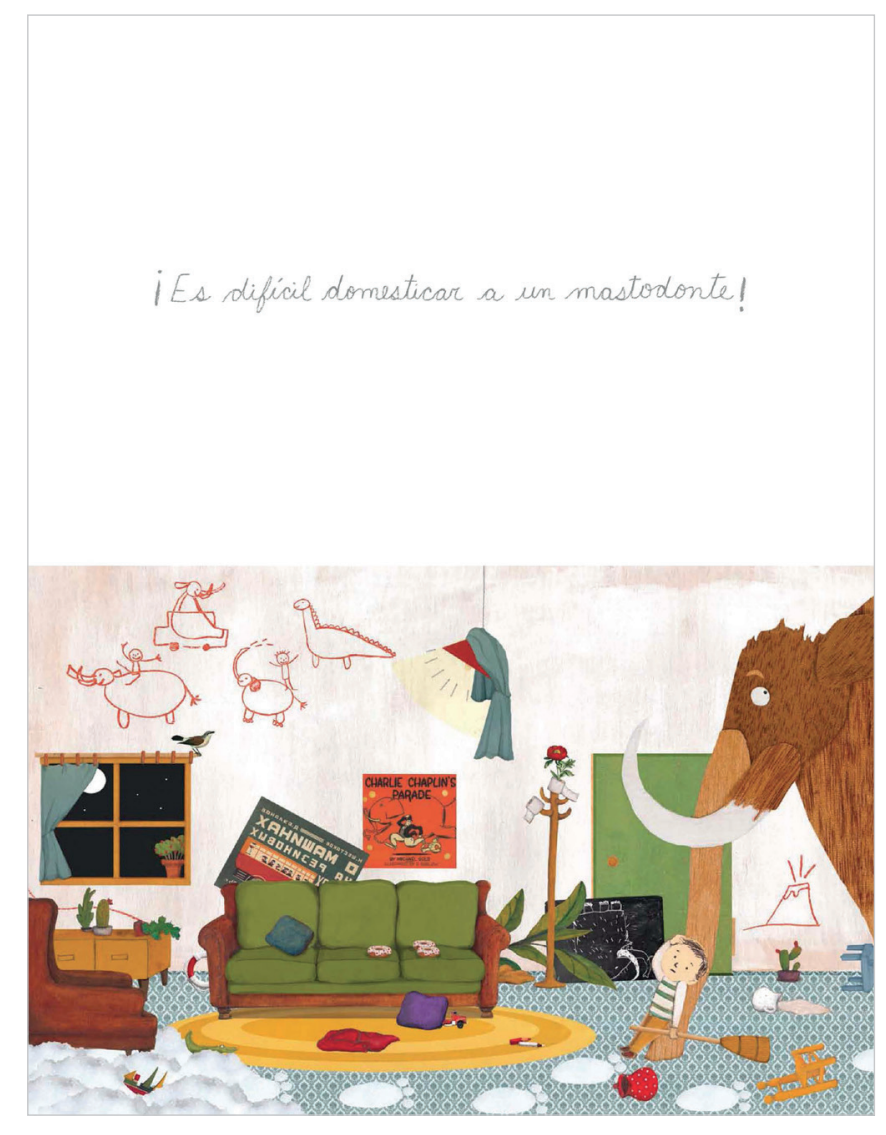

Figura 4

8 Para Van der Linden (2015), la complementariedad se produce cuando texto e imagen "están en relación mutua, o bien porque cada uno aporta una dimensión suplementaria al otro" (p. 17). Es decir, existe una interdependencia entre ambos, texto e imagen solo "caminan juntos". 
Este libro álbum presenta imágenes articuladas, si bien existen brechas de interpretación entre una y otra escena. La articulación se produce por la lógica espacial empleada para la ubicación de los personajes (el niño aparece a la izquierda y el mastodonte a la derecha), la repetición de la acción base (el niño da una orden al mastodonte y este se niega) y de escenarios. Cabe destacar que las imágenes altamente articuladas se reservan para el momento de la narración sin palabras señalado anteriormente.

Por otro lado, se observa un uso narrativo de los peritextos, como la tapa y la portada, donde se sugiere una "clave de lectura" para acercarse a la historia. En la tapa se presenta la acción base antes mencionada y se muestra a los personajes en la ubicación repetitiva en la que aparecerán en las primeras escenas. Asimismo, en la portada se observa la trompa del mastodonte sosteniendo el lápiz rojo y haciendo un dibujo, de manera que el lector ya sabe que lo que encuentre escrito con este color corresponde a la voz de este personaje (figura 5). Cabe destacar que en la contratapa se aprecia un dibujo en la pared hecho con el lápiz rojo, lo que permite ampliar el final sugiriendo que el mastodonte seguirá con sus travesuras.

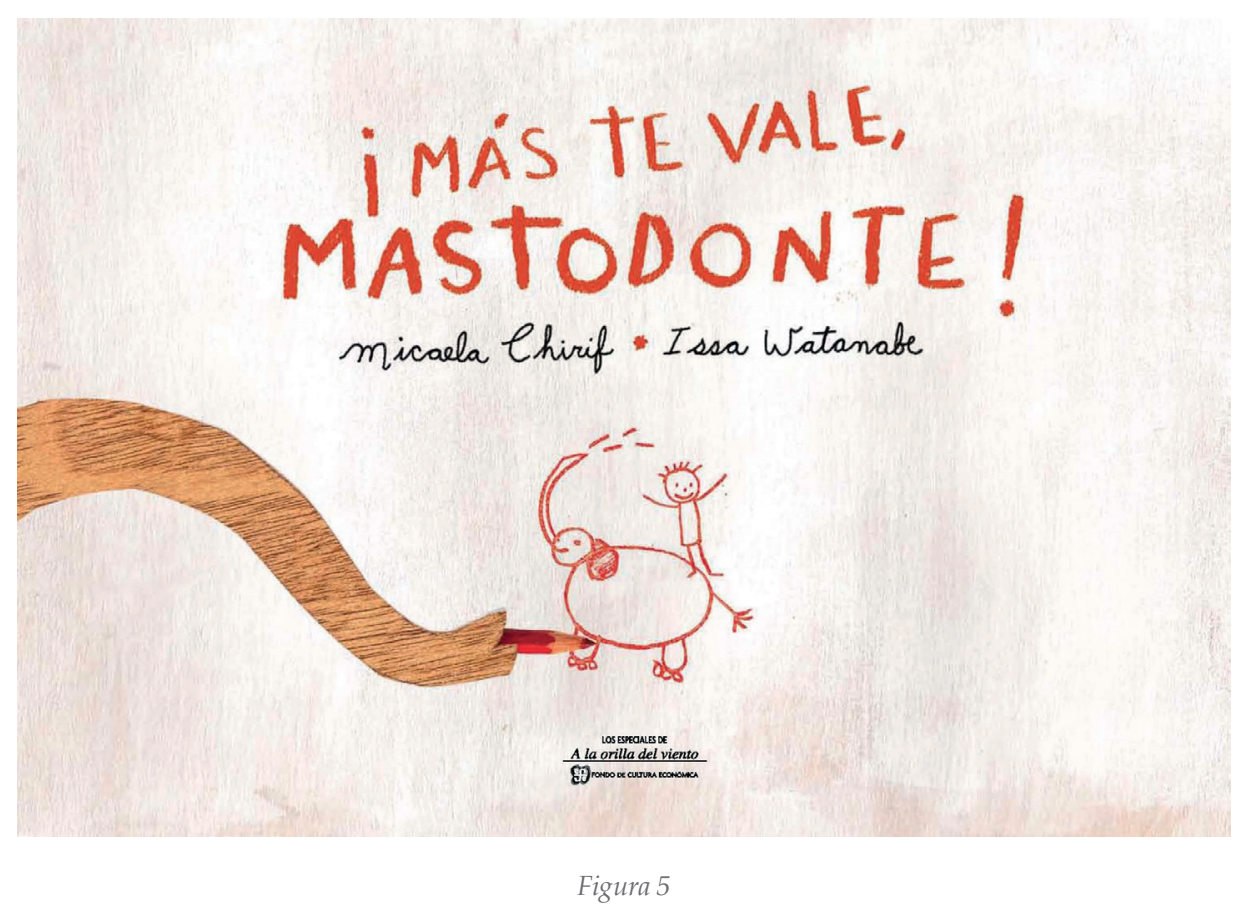

Otro elemento importante para esta narración es el formato de grandes dimensiones que tiene el libro $(40 \mathrm{~cm} \times 25 \mathrm{~cm}$ ), el cual es coherente con el gran tamaño de un mastodonte. Lo mismo ocurre con las tipografías (figura 6) que permiten diferenciar la voz del niño (letra infantil, a lápiz, trazo suave) y del mastodonte (grande, trazo grueso y rojo). 


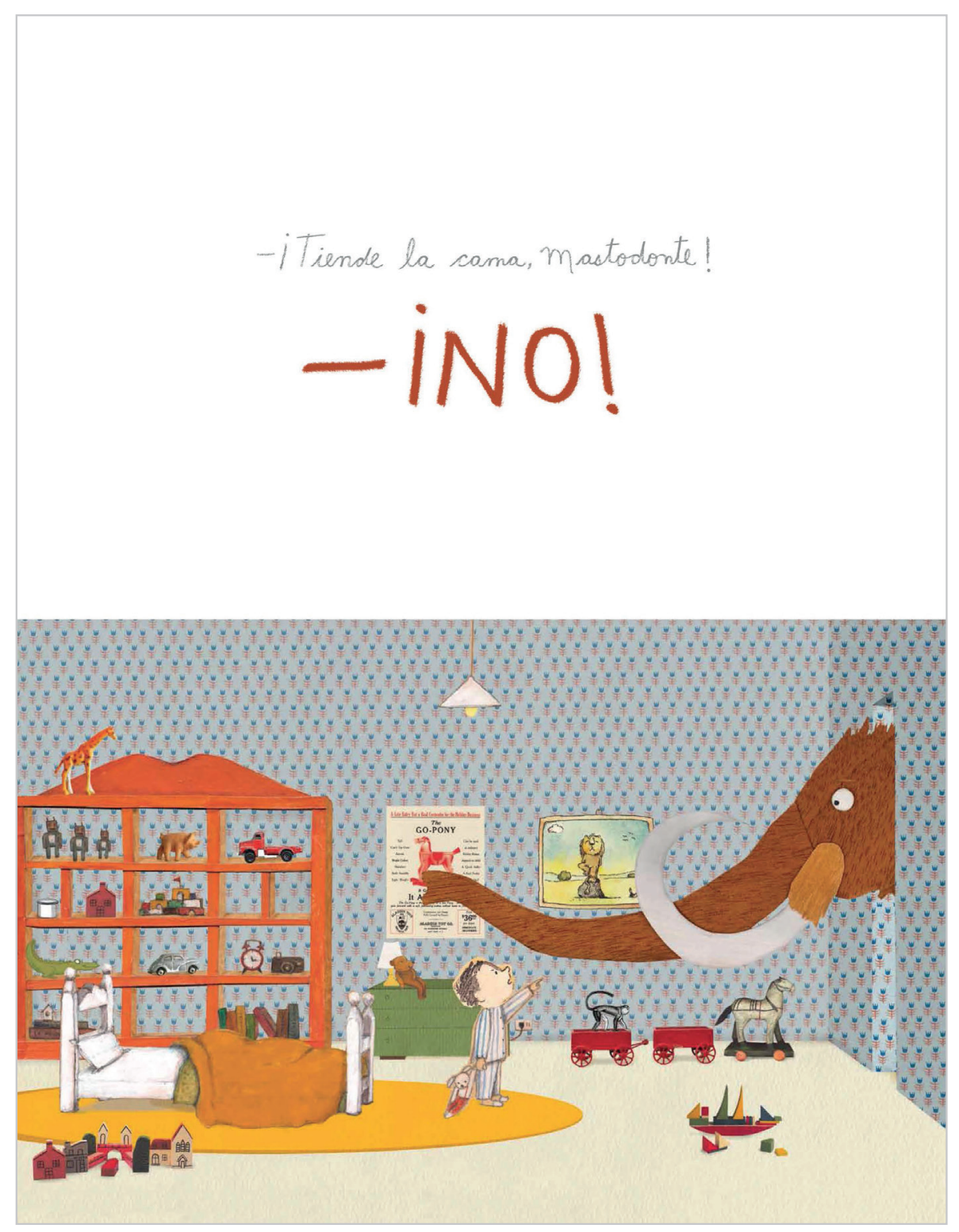

Figura 6

\section{Gato de mercado (SM, 2105)}

Con textos e ilustraciones de Christian Ayuni, presenta el testimonio en primera persona de un gato de mercado, quien desde el inicio marca distancia de los gatos techeros y los de casa, pues su vida es mucho más divertida. Sin embargo, al final se descubre que si bien durante el día es un gato de mercado, en la noche vuelve a los brazos de su dueña y al calor de su hogar. 
Esta historia es narrada por la interacción entre texto e imagen puestos en la página de manera asociada. La extensión del final en la última página y la guarda final ${ }^{9}$, en las que vemos al gato saliendo del libro como si fuera a seguir sus aventuras, sí recurren a la narración solo con imágenes. La relación texto-imagen alterna entre la amplificación y la complementariedad, siendo esta última usada para la revelación final del desenlace. Cabe destacar que también se hace presente la ironía de manera transversal al leer lo que el protagonista opina sobre los gatos caseros (a quienes considera aburridos) y descubrir al final que él es uno de ellos (figura 7).

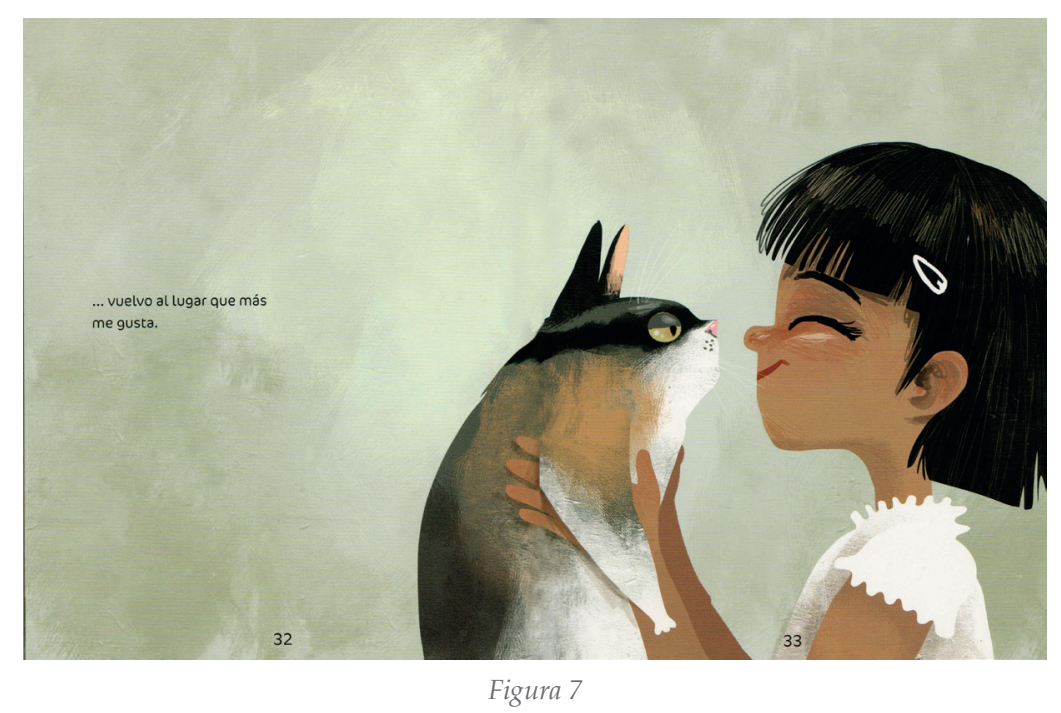

En cuanto a la secuenciación de las imágenes, alterna entre las aisladas y las articuladas. Opta por estas últimas en los dos momentos más importantes: cuando el gato describe su recorrido por los puestos del mercado y cuando se encuentra con su dueña al final del día. Es justamente en este último momento cuando se aprecia la mayor brecha de significación, ya que el lector deberá descubrir la ironía del final.

Como ya se mencionó con anterioridad, se hace un uso narrativo de las guardas aprovechando el soporte libro (figura 8). En ellas, se utilizan los ícono-textos para hiperbolizar los múltiples nombres que tiene un gato de mercado y que le permiten vivir muchas vidas a la vez. Un recurso similar se aprecia en las páginas 14 y 15 cuando el gato se expresa sobre este punto (figura 9).

9 La encuadernación del libro es rústica; sin embargo, se ha aprovechado el lado interno de las tapas (retira), la primera y la última página para simular unas guardas. 


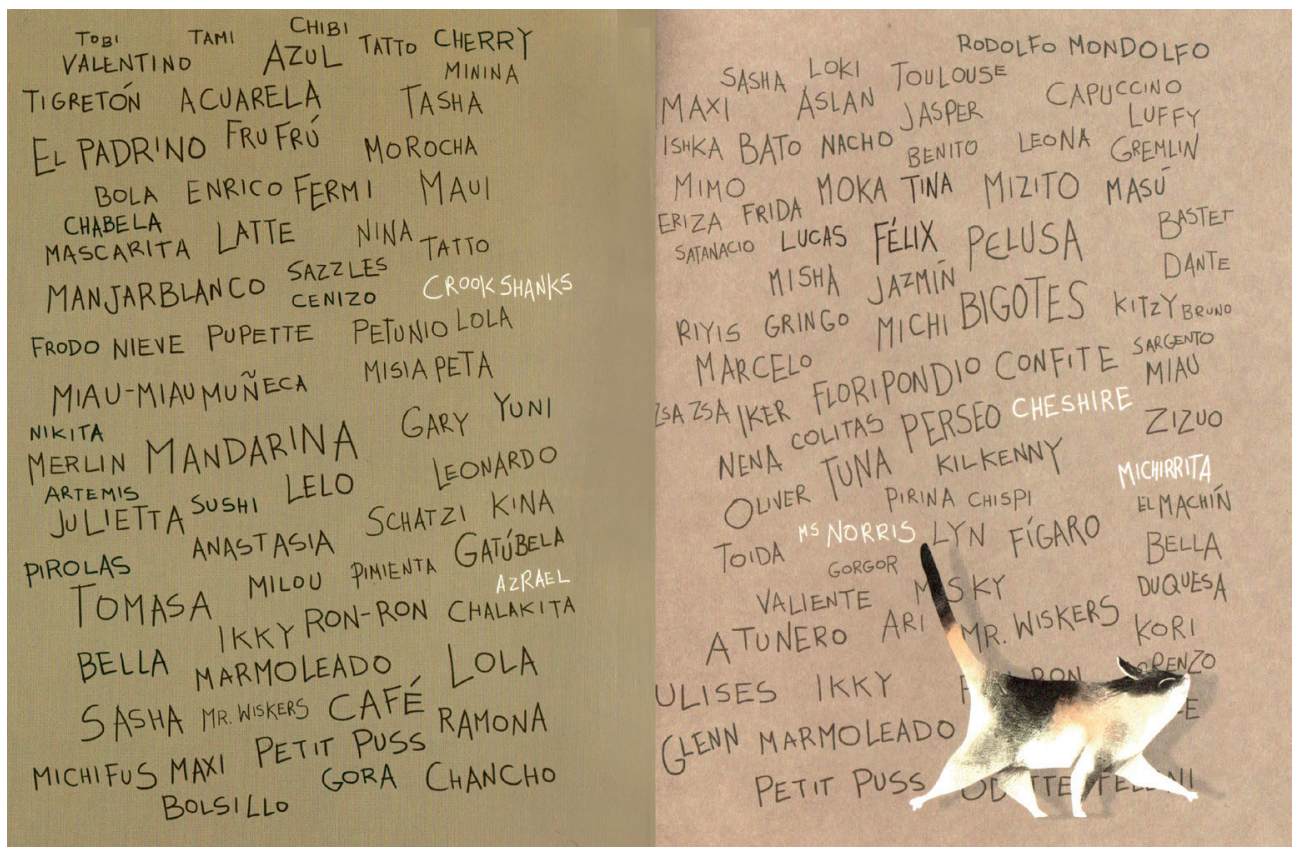

Figura 8

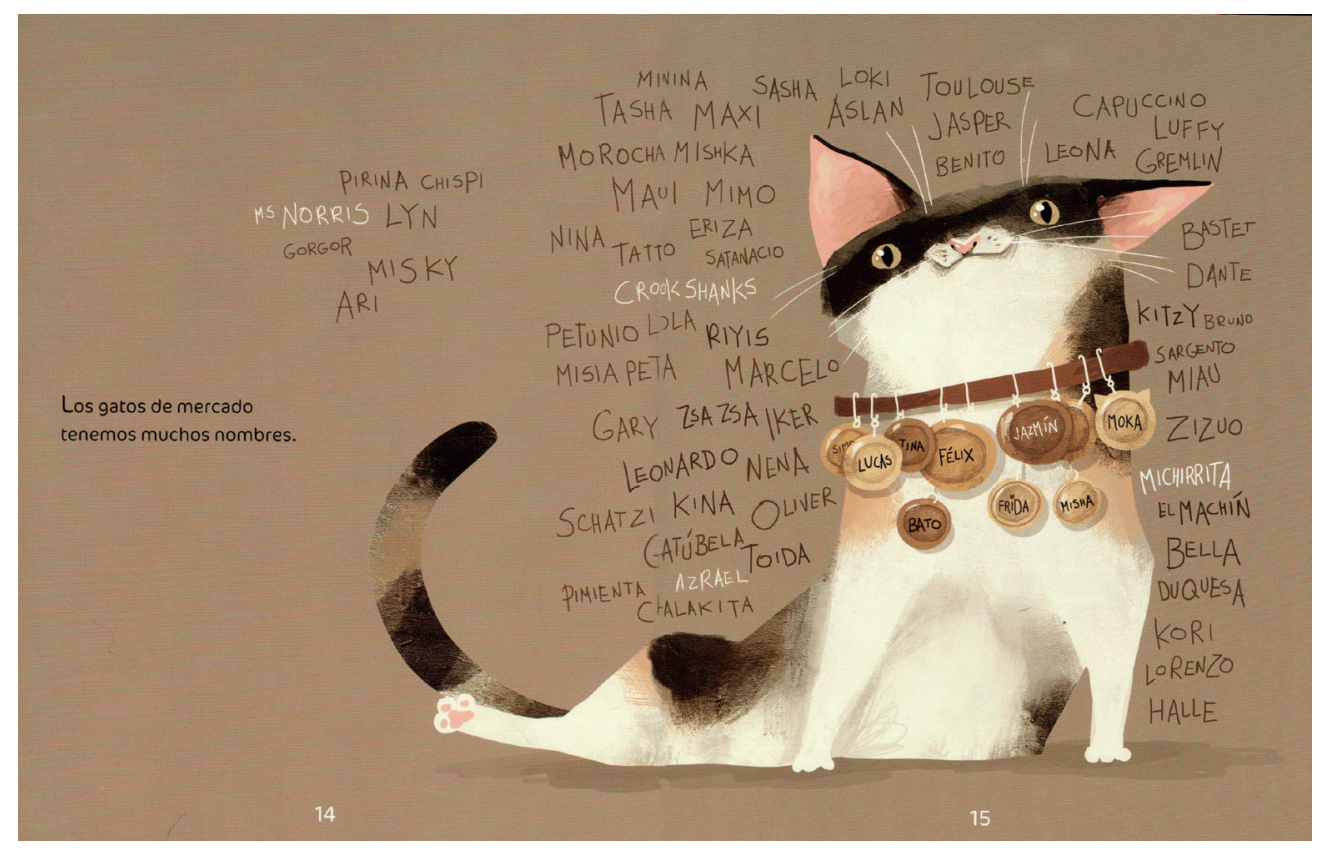

Figura 9 


\section{La banda (Polifonía Editora, 2015)}

Con textos e ilustraciones de Cocoretto $^{10}$, presenta a los integrantes de una banda tocando sus diferentes instrumentos durante la tarde hasta que alguien pide silencio al llegar la noche. En lugar de callarse, siguen con el bullicio.

En este libro álbum, notamos mayor autonomía del texto con respecto a las ilustraciones en gran parte de sus dobles páginas, y la relación texto-imagen predominante es la amplificación. Sin embargo, en el desenlace (cuando la banda sigue tocando) se recurre a la interacción entre texto e imagen en relación de complementariedad, con una puesta en página asociada (figura 10).

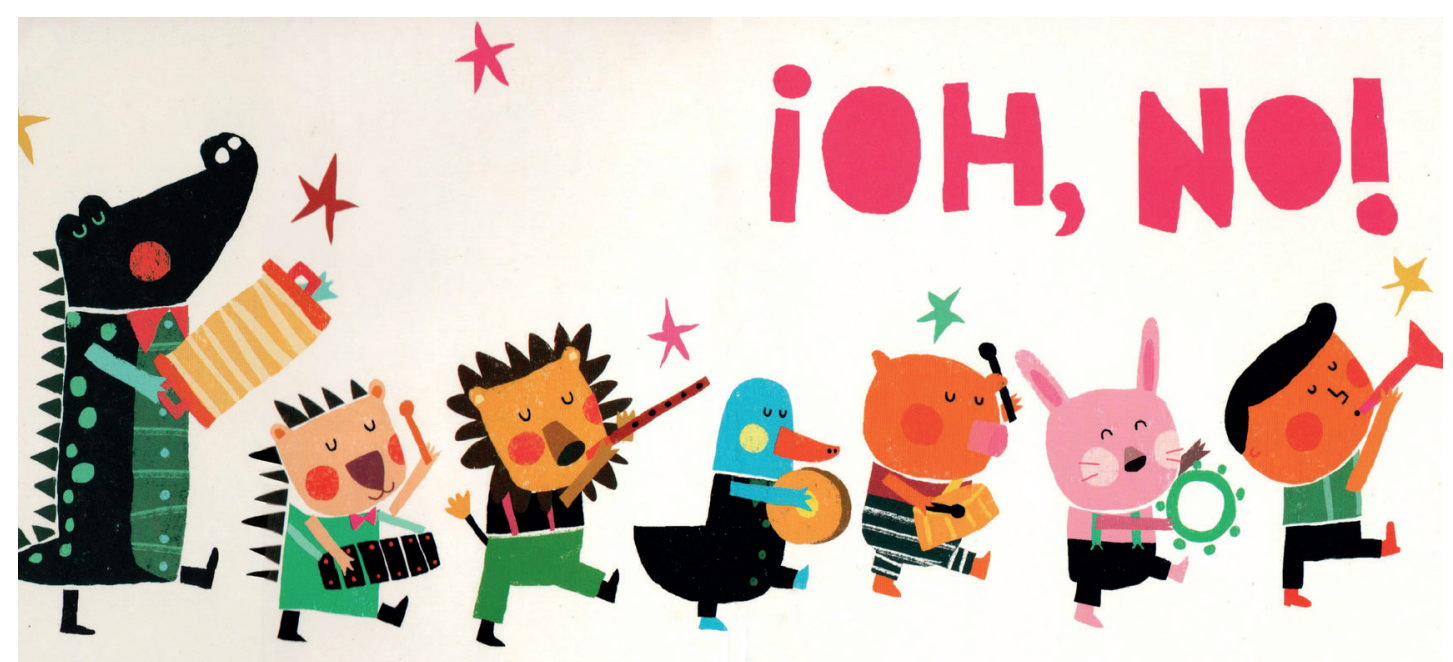

¡Pero si solo es el comienzo!

Figura 10

Cabe destacar que, si bien no son imprescindibles, los ícono-textos que reproducen las onomatopeyas de los instrumentos contribuyen a reforzar la idea del bullicio generado por la banda, elemento central para el conflicto (figura 11).

10 Cocoretto es el seudónimo bajo el cual dos ilustradores peruanos decidieron unir su trabajo desde el 2013. 


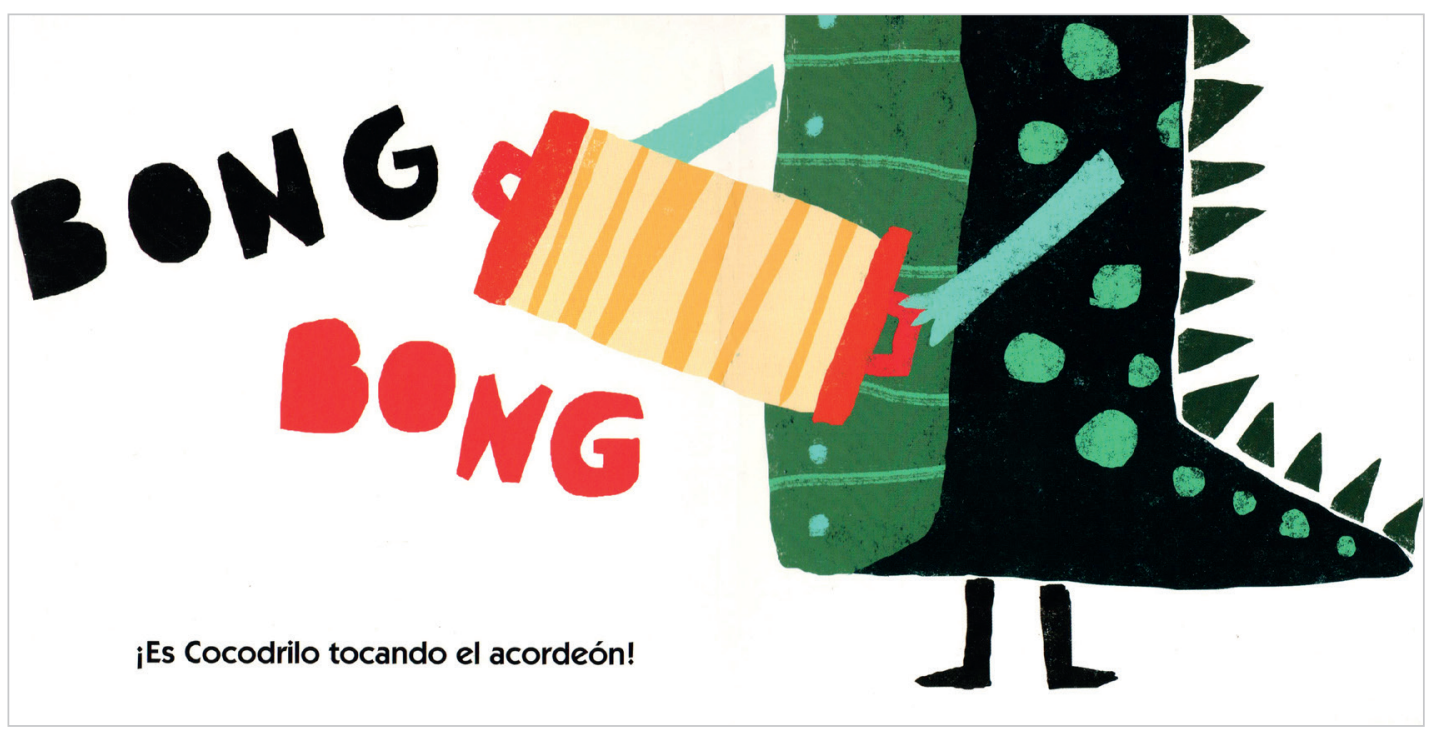

Figura 11

Por ser menor la interacción entre texto e imagen, se presentan menos brechas de interpretación. Lo que sí tiene un rol muy importante es la lógica espacial que se ha seguido para distribuir los elementos en la doble página. Así, el elemento principal de las ilustraciones (casa y personajes) aparece siempre a la derecha y las onomatopeyas, a la izquierda. Los textos siempre están en la dirección hacia donde miran los personajes. Es notorio que esta cambia en la doble página final y apunta hacia la derecha para reforzar la idea de que la banda seguirá tocando y la historia continúa.

En la narración, se emplean imágenes articuladas y se integra en ella a la contraportada, donde se muestra a los integrantes de la banda durmiendo, posiblemente luego de haber estado tocando (figura 12). Por otro lado, la tipografía con la que se han representado las onomatopeyas (grande, de trazo grueso, con todas las letras en mayúsculas) transmite la idea de que son sonidos fuertes que irrumpen en la tranquilidad de la tarde o noche. 


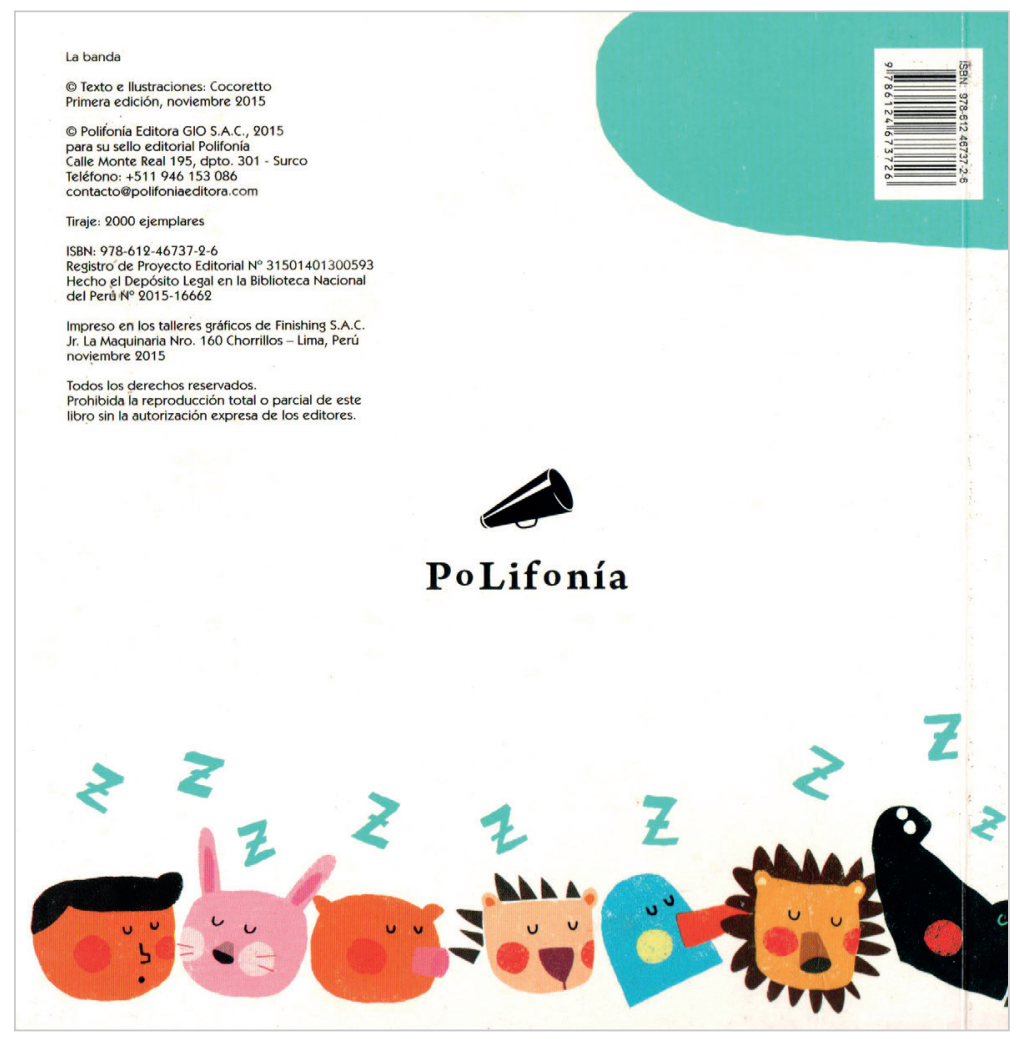

Figura 12

\section{ENTRE EL LENGUAJE DEL LIBRO ÁLBUM Y EL LIBRO ILUSTRADO}

Puesto que son pocas las publicaciones que emplean la mayoría de los recursos del lenguaje de los libros álbum en nuestra producción editorial, es oportuno destacar también aquellas en las que se aprecian muchos de ellos y algunos instantes de relación texto-imagen que superan la amplificación, aunque el texto pueda leerse solo y la imagen tenga poco peso narrativo. Se trata de tres libros que forman el 9,7 \% de la muestra, en los que se observó imágenes articuladas, la presencia de una lógica espacial y el uso de la imagen para describir los personajes y escenarios.

\section{El vigía (MALI, 2013)}

Este libro destaca por el uso narrativo de los peritextos, ya que en las guardas iniciales (figura 13) se ve al niño protagonista lanzando una pelota cuyo recorrido se sigue en la portadilla (figura 14), la página de créditos y la portada (figura 15) hasta que llega donde está el vigía, dando a entender que el niño se encuentra con este personaje por seguir su pelota. Es decir, la historia empieza en las guardas usando imágenes 
altamente articuladas y la narración sin palabras. En las guardas finales, se presenta una escena similar: el vigía lanza un avión de papel y este vuela hacia las últimas páginas del libro.

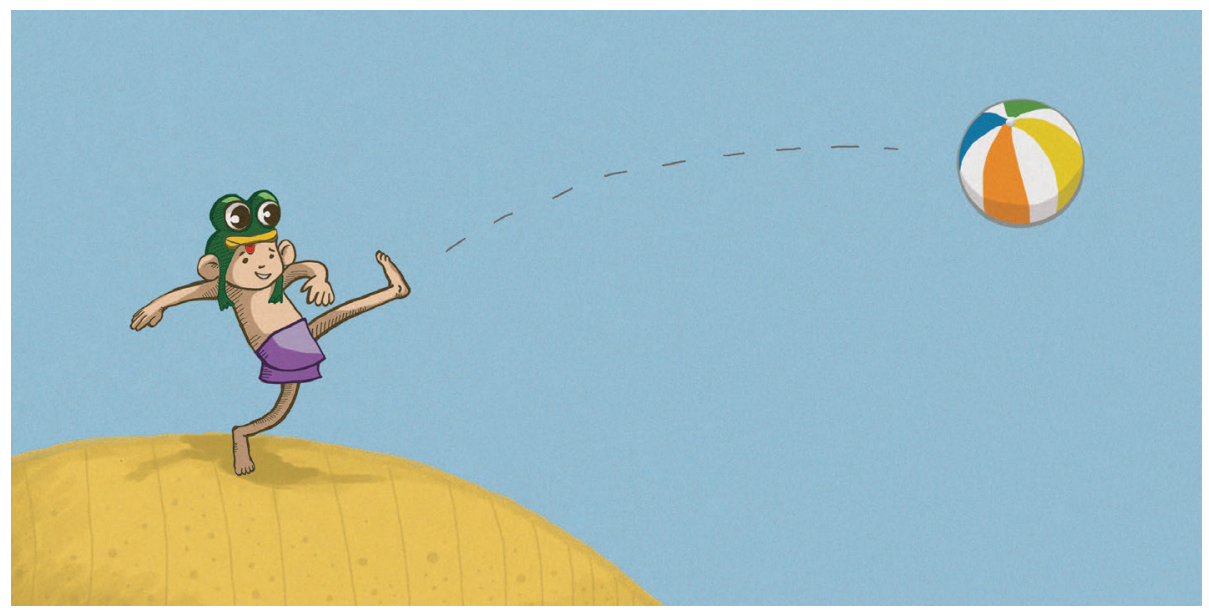

Figura 13

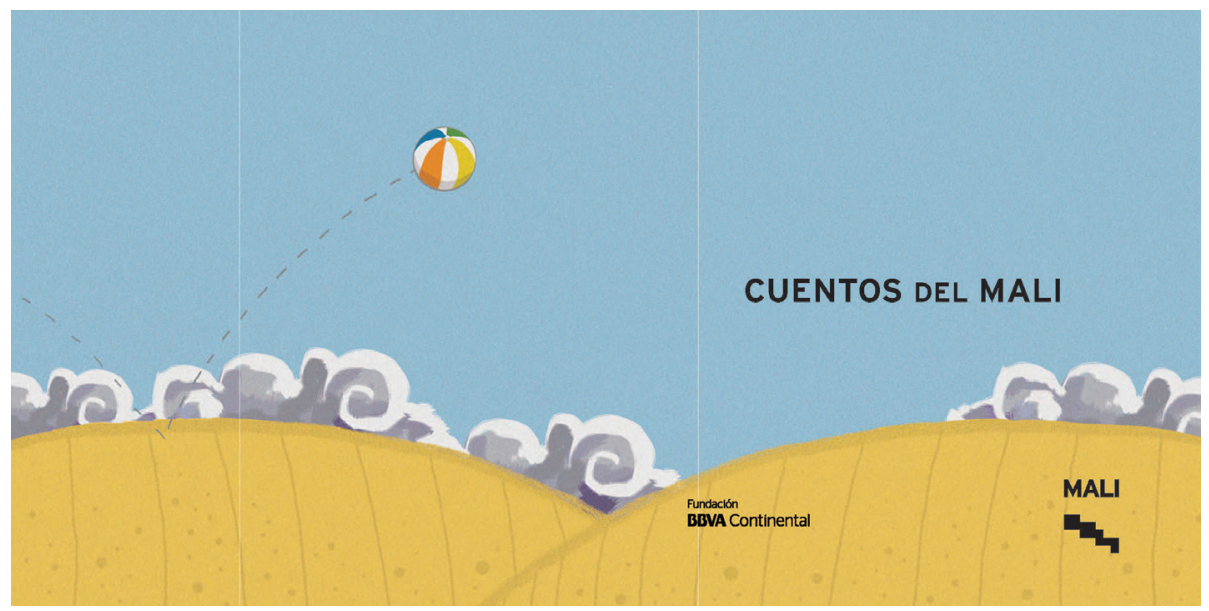

Figura 14 


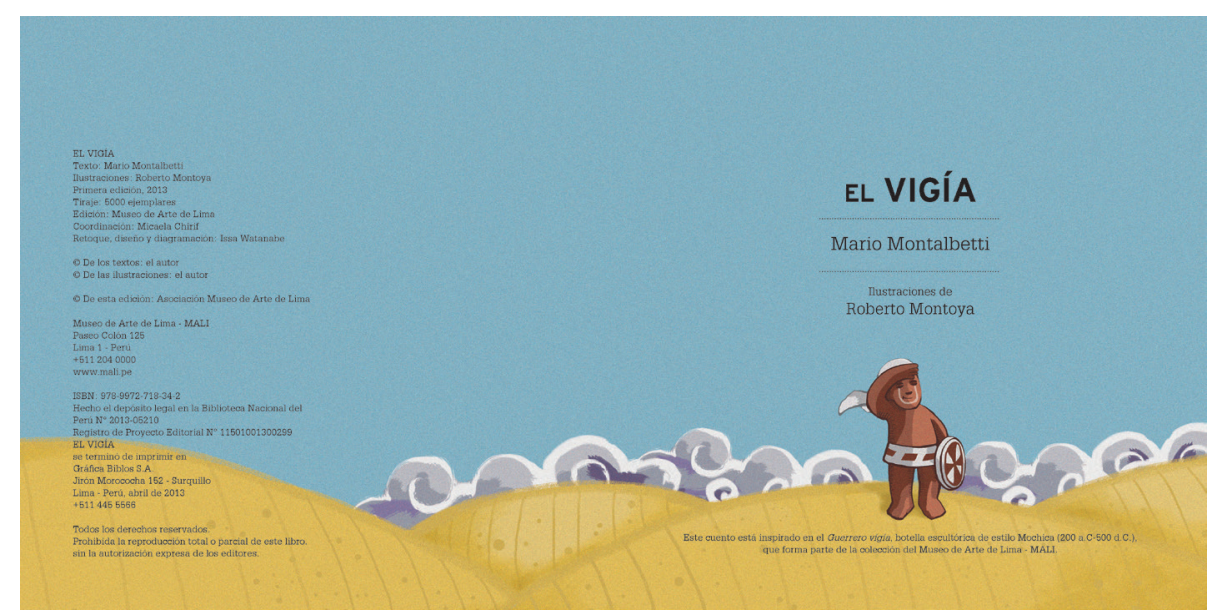

Figura 15

Por otro lado, tenemos una escena de interacción entre texto e imagen en las páginas 20 y 21, ya que la imagen complementa el mensaje cuando el niño dice: "así" y realiza un gesto demostrativo (figura 16). La ilustración marca el momento del día en que ocurre la historia y el soporte es aprovechado, puesto que la doble página, el formato apaisado y la ausencia de márgenes destacan la inmensidad de la playa.

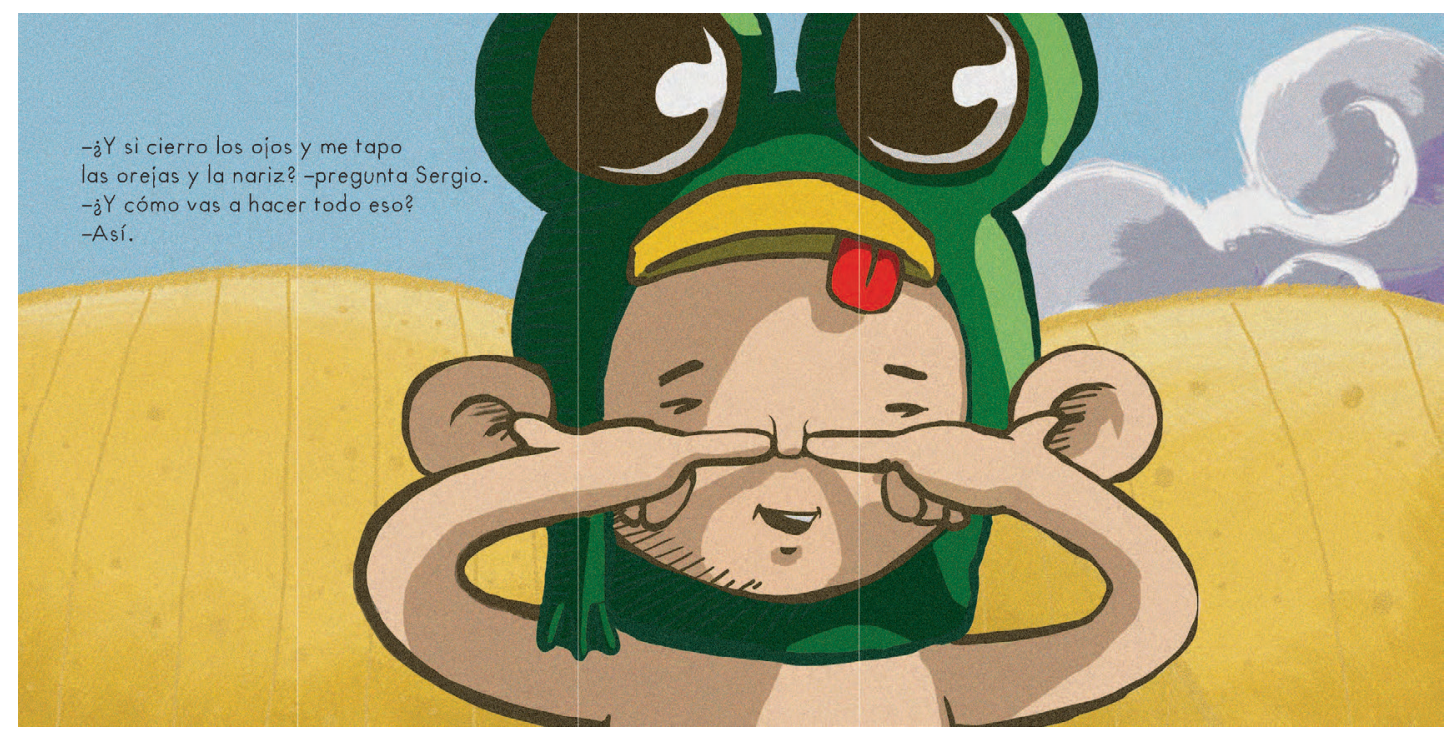

Figura 16 


\section{Las pequeñas aventuras de Juanito y su bicicleta amarilla} (Polifonía Editora, 2014)

En este libro-disco, se aprecia un uso narrativo de la tapa y la contratapa (figura 17) donde se establece la lógica espacial que se sigue en todo el libro: el lector acompaña el recorrido de Juanito en su bicicleta con el pasar de las páginas, lo que evidencia un uso narrativo del soporte.

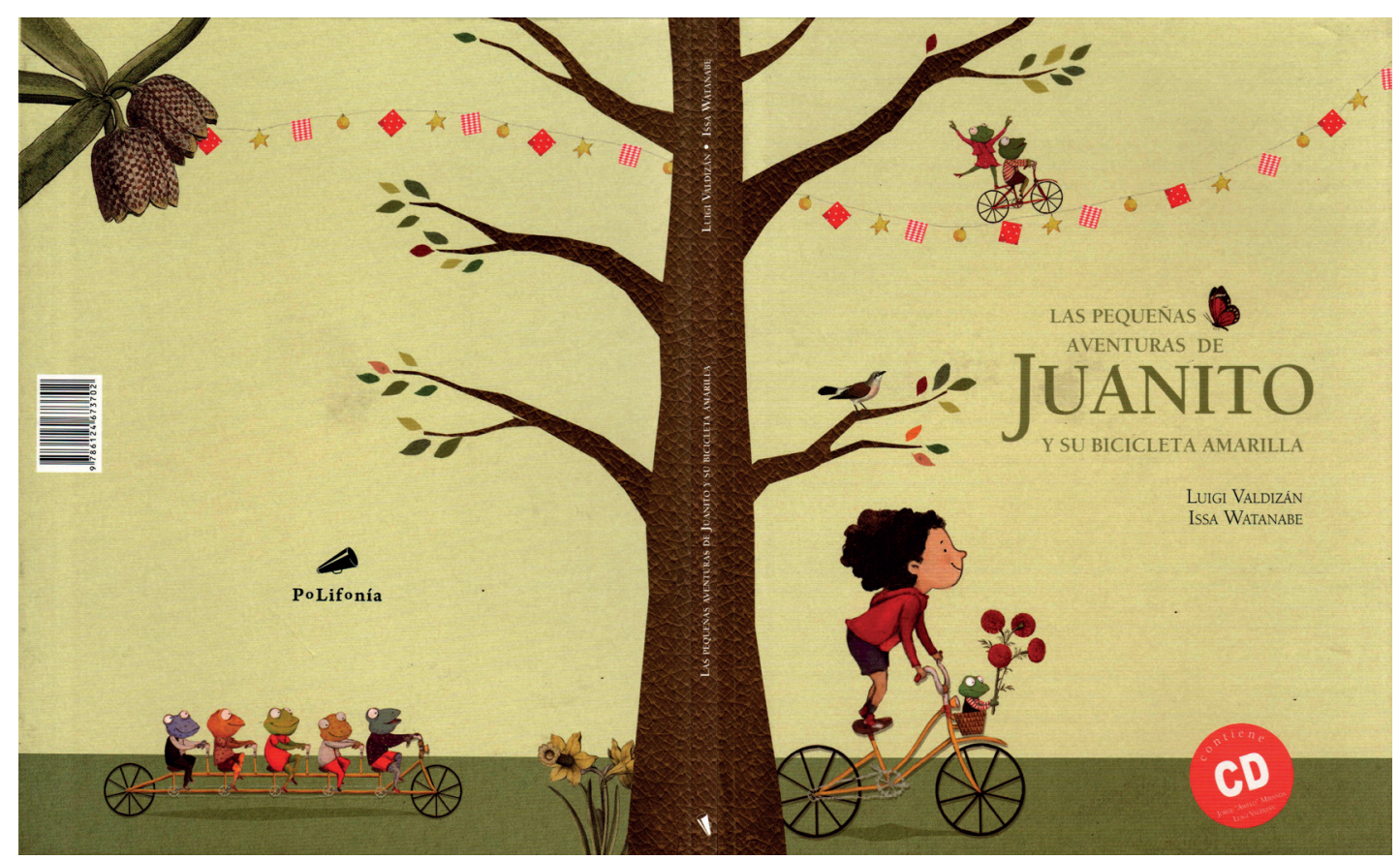

Figura 17

Asimismo, se usan narrativamente la portada y la hoja de créditos donde se aprecia la continuidad de la cadeneta de la tapa y un sapito pedaleando, de manera que se anuncia su presencia a lo largo del texto. Sobre él no se dice nada en el texto, pero sus acciones continuas constituyen una línea narrativa paralela cuyo peso recae exclusivamente en la imagen.

Si bien el texto es autónomo, es notorio el alto grado de amplificación que tienen las ilustraciones al mostrar escenas completas llenas de acción a partir de breves menciones. Por ejemplo, el texto dice que "había una fiesta de batracios sin control" y en doble página encontramos una ilustración que nos muestra a muchos sapos interactuando y divirtiéndose de diversas maneras (figura 18). 


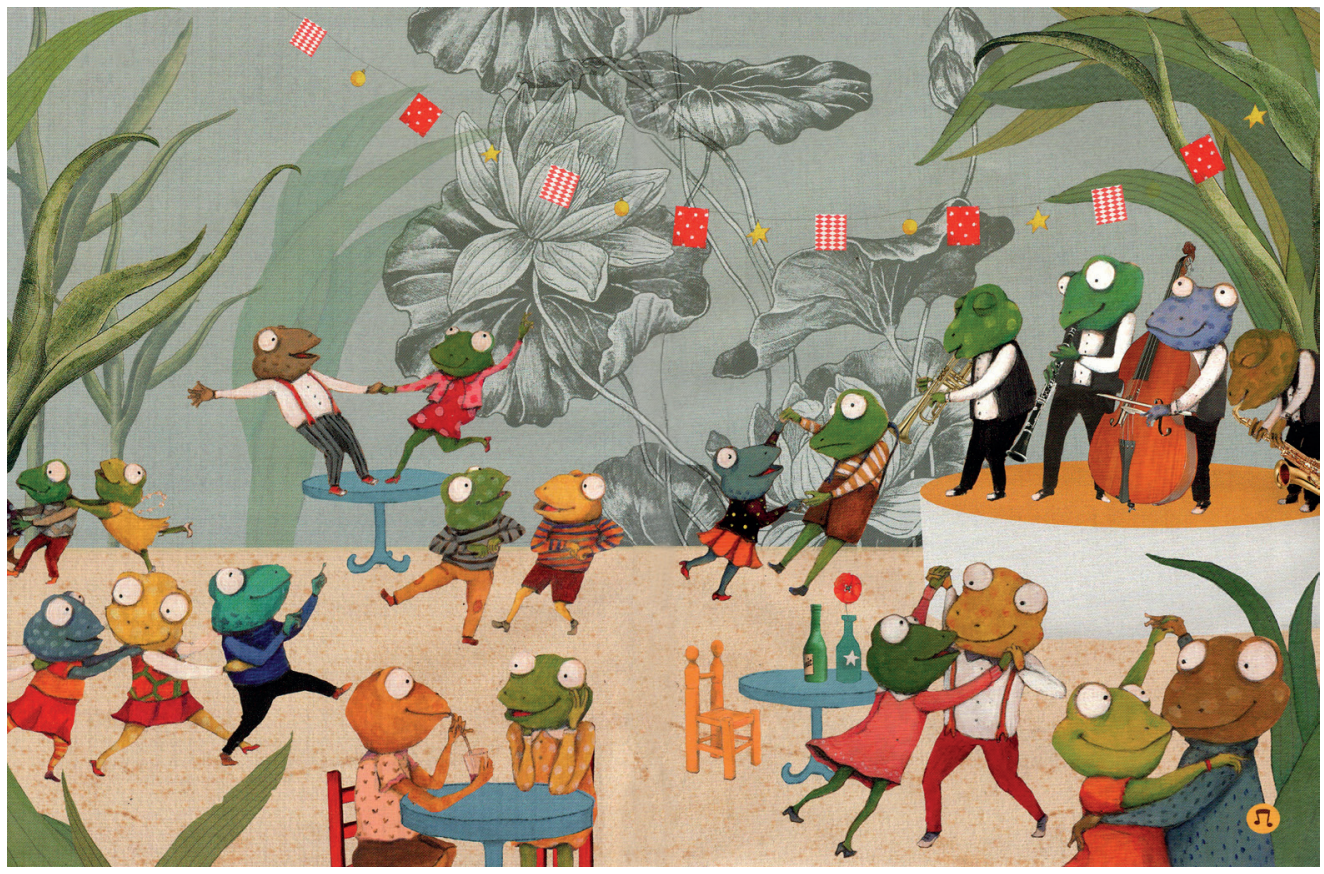

Figura 18

\section{La lavandera (MALI, 2013)}

Se trata de un cuento que, como tal, puede leerse sin las ilustraciones. No obstante, destaca el uso intencionado de dos páginas individuales con imágenes altamente articuladas para disminuir el ritmo y que el lector se detenga en ese momento crucial en que la lavandera se eleva y empieza a volar (figura 19). Por otro lado, la lógica espacial da la impresión de que la lavandera vuela por las páginas del libro (pp. 18-30) y que avanza cada vez que pasamos una doble página (figura 20).

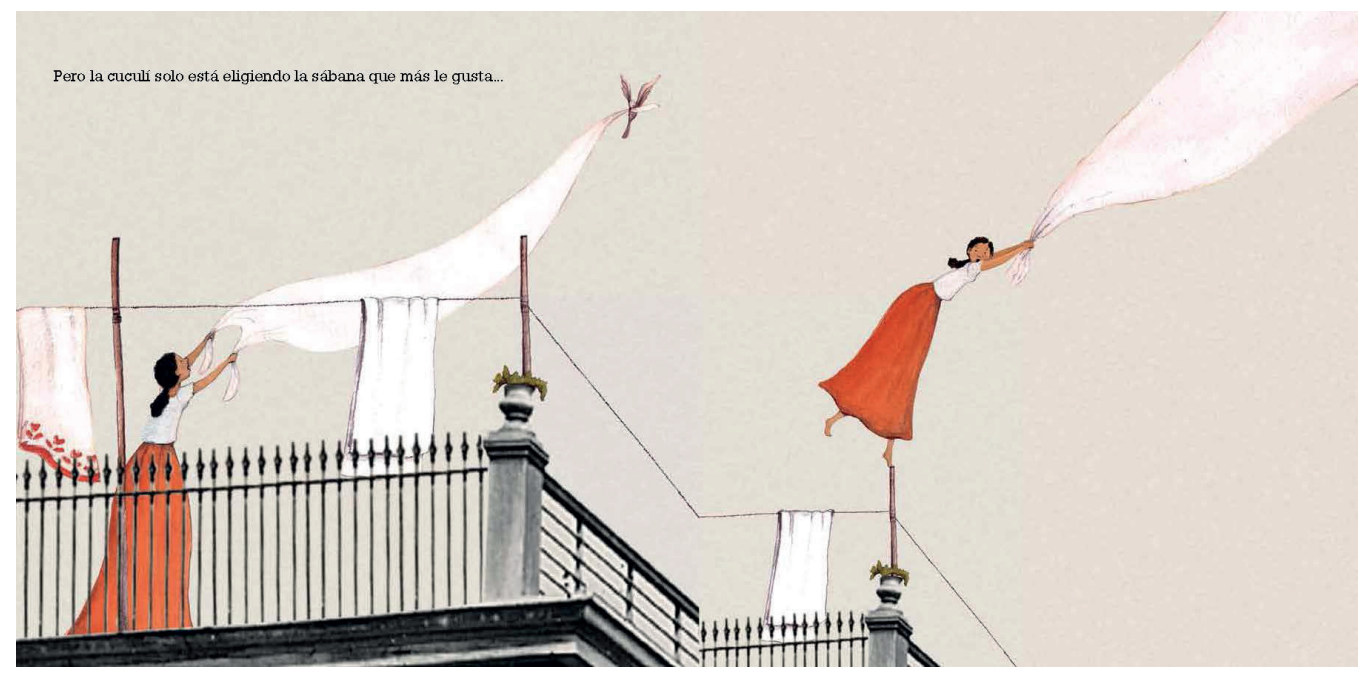




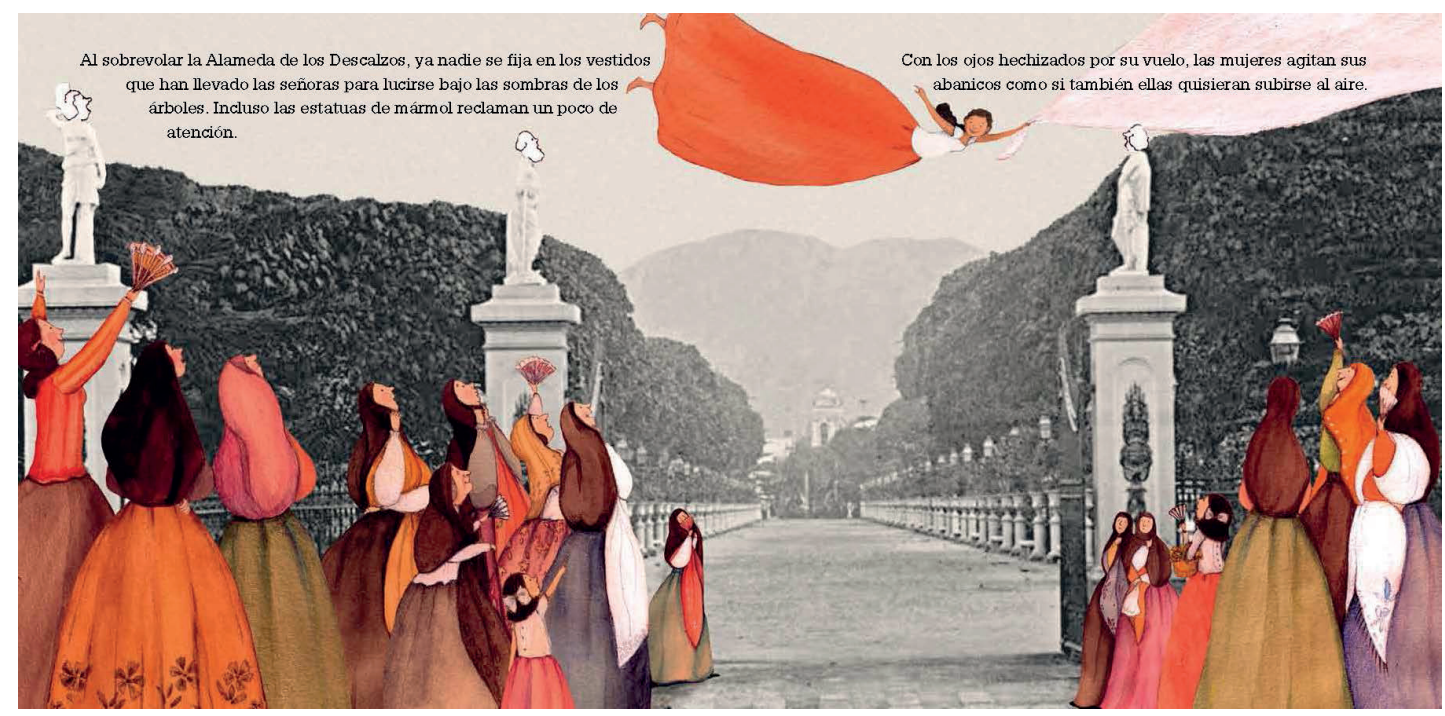

Figura 20

\section{ALGUNAS CONCLUSIONES}

Si bien los 31 libros analizados responden a la definición de libro álbum, es notorio que la mayoría de ellos presentan características que los acercan más al lenguaje del libro ilustrado. En lo que respecta a la narratividad, en el 92,3 \% el texto se puede leer solo, lo que coincide con el hecho de que son pocos los libros en los que la imagen tiene valor narrativo (12,9 \% de manera constante y 16,1 \% ocasionalmente) y que la forma de relación texto-imagen más extendida sea la amplificación (96,8 \%). Por consiguiente, las brechas de interpretación son poco frecuentes $(16,1 \%)$, ya que a pesar de predominar las imágenes aisladas (83,8 \%), los vacíos son completados por el texto. El tiempo es casi siempre marcado por el texto $(87,1 \%)$ y el uso narrativo del soporte es minoritario $(32,3 \%)$, generalmente aprovechado para reforzar la idea de tránsito o recorrido con el paso de una doble página a otra. Lo mismo ocurre con la utilización narrativa de los peritextos, presente tan solo en el 29 \% de la muestra. Entre estos, el más empleado es la contratapa (16,1 \%) para ampliar el final del libro.

En el otro extremo, de mayor cercanía con el lenguaje del libro álbum, se aprecia una preferencia por la doble página (61,3 \% de manera exclusiva), en la que predomina la puesta en página asociada (87,1 \%). Asimismo, el uso narrativo de un elemento gráfico, como la tipografía $(48,4 \%)$ para destacar onomatopeyas, exclamaciones o gritos, y la existencia de una lógica espacial (54,8 \%), a pesar de la poca articulación predominante. También se observa que la descripción de personajes y la presentación de escenarios generalmente recaen en la ilustración (93,5 \% y 64,5 \%, respectivamente). 
Como ya se explicó antes, son pocas las publicaciones que aprovechan la mayoría de los recursos que ofrece el lenguaje propio del libro álbum (12,9\%). Sin embargo, es loable el hecho de que algunas de estas cuenten con importantes distinciones y meritorio el trabajo de un sello como Polifonía Editora, que tiene el firme empeño de desarrollar este tipo de proyectos. En cuanto a los autores, se observan nombres que por su trayectoria podemos asociar rápidamente con el trabajo del libro álbum en el Perú, tales como Micaela Chirif, Issa Watanabe, Gabriel Alayza y Cocoretto ${ }^{11}$. Asimismo, Christian Ayuni cuenta con una destacada labor como autor-ilustrador.

En cuanto a la clasificación de las publicaciones de la muestra, se observó que en general no se menciona qué tipo de libro es y en la prensa se prefiere el genérico "libro". Solo se emplea con claridad el término libro álbum en el caso de los premiados, probablemente porque esto permite menos posibilidad de error en cuanto al uso del término.

\section{UN PANORAMA ACADÉMICO FAVORABLE}

Por último, conviene destacar que el año posterior al período estudiado (2016) ha resultado favorable en cuanto al acercamiento académico a este tipo de publicaciones en el Perú debido a la organización de varias charlas y encuentros sobre el libro álbum, que contaron con la participación de reconocidos especialistas internacionales, como Pascal Humbert (Francia), Cecilia Silva-Díaz (Venezuela) y Pablo Larraguibel (Chile). Además, la Casa de la Literatura Peruana organizó un semillero de libro álbum, dirigido por Fanuel Díaz (Venezuela) y que reunió a escritores, ilustradores y editores. Por otro lado, también se desarrolló el primer taller de lectura de libros álbum, organizado por la especialista y autora peruana Micaela Chirif.

Como puede observarse, el libro álbum está ganando espacios en el Perú, tanto en la producción editorial como en los círculos académicos, y genera un interés cada vez mayor. Si bien su camino recién empieza, sus primeros pasos son meritorios y abren muchas puertas para el desarrollo de proyectos editoriales, investigaciones, crítica y debate académico.

11 Así lo demuestran otros libros álbum publicados antes o después del período analizado en este estudio, tales como El pájaro pintado (José e Issa Watanabe, 2007), En forma de palabras (Chirif y Alayza, 2012), ¿Dónde está Tomás? (Chirif y Salaberria, 2016) y Nuno juega (Eslava y Cocoretto, 2016). 


\section{ANEXO. ALGUNOS AÑOS DESPUÉS}

Durante los años posteriores a la culminación de este estudio, el libro álbum siguió un curso favorable en el sector académico y editorial peruano, con mayor producción de los autores ya mencionados anteriormente y con nuevas apariciones, aunque sin llegar a tener la relevancia que ha tenido en otros países de América. En cuanto a las actividades académicas, las charlas y talleres sobre este tipo de publicación fueron en aumento, organizadas principalmente por Íbero Librerías y el Fondo de Cultura Económica Perú, y dictadas por Micaela Chirif (quien también ha impartido charlas y talleres sobre este tema en eventos internacionales), Irina Burgos y Daniela Alcalde, entre otros especialistas. Además, el Minedu volvió a solicitar libros álbum para la implementación de bibliotecas escolares por medio de las licitaciones públicas n. ${ }^{\circ}$ 007-2018 y n. 003-2019.

En lo que se refiere a la producción editorial, el 2017 Polifonía Editora participó por primera vez en la Feria del Libro Infantil de Bolonia, el evento editorial más importante para el sector infantil a nivel mundial. Además, continuó su línea de publicaciones con libros álbum como La pequeña niña (2017), de Luigi Valdizán y Beatriz Chung, el cual fue parte de la Lista de Honor IBBY 2018; y con Las interminables preguntas de Juanito y su bicicleta amarilla (2017), de Luigi Valdizán y Natalí Sejuro. Además, durante el período mencionado también publicaron libros álbum para prelectores: Vamos a... (2016), de Cocoretto; La discusión (2019), de Andrea Gago; y Plin plin (2019) y Pon pon (2019), ambos del ilustrador Motoneta.

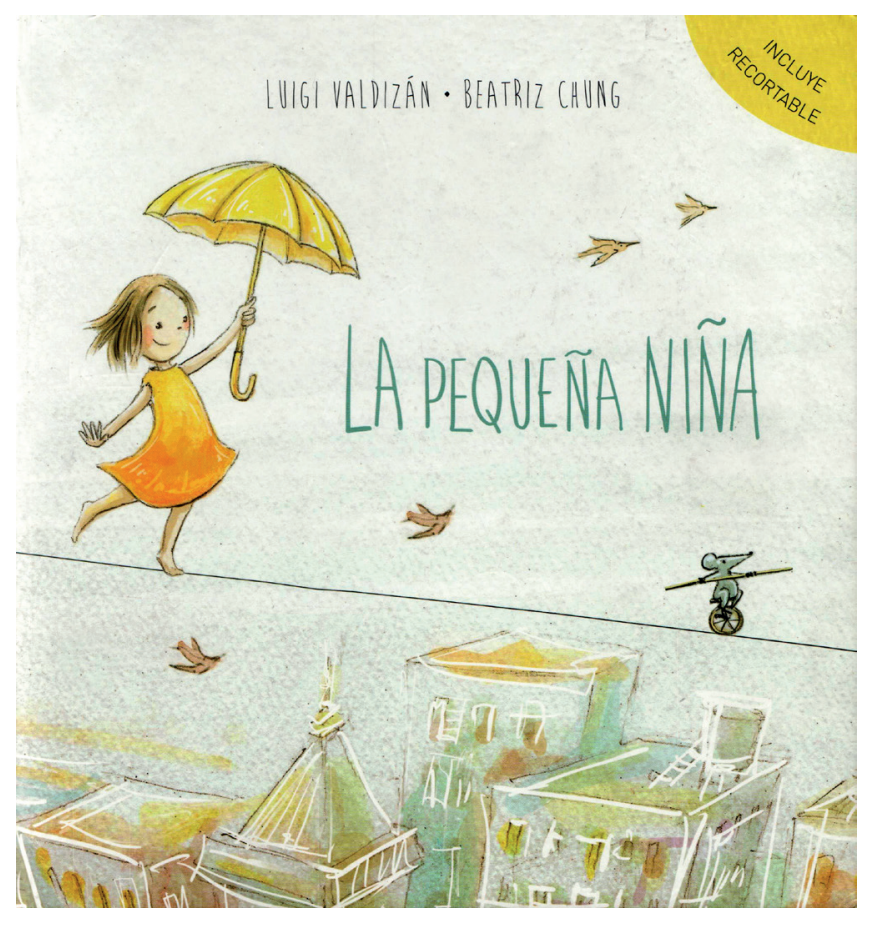


También aparecieron nuevas propuestas editoriales destinadas al público infantil, como el sello Ludo, de Estación La Cultura, que inició la colección Problema \& Posibilidad con dos libros álbum de Jorge Eslava: La carpeta vacía (2017), ilustrado por Andrea Lértora, y La puerta oscura (2017), ilustrado por Carmen García. Este también fue el caso de Ediciones Pichoncito, que publicó El armadillo que quería jugar (2018), libro álbum de Julia Viñas y Lucía Coz, que resultó ganador de la categoría de ilustración de los Latin American Design Awards 2019.

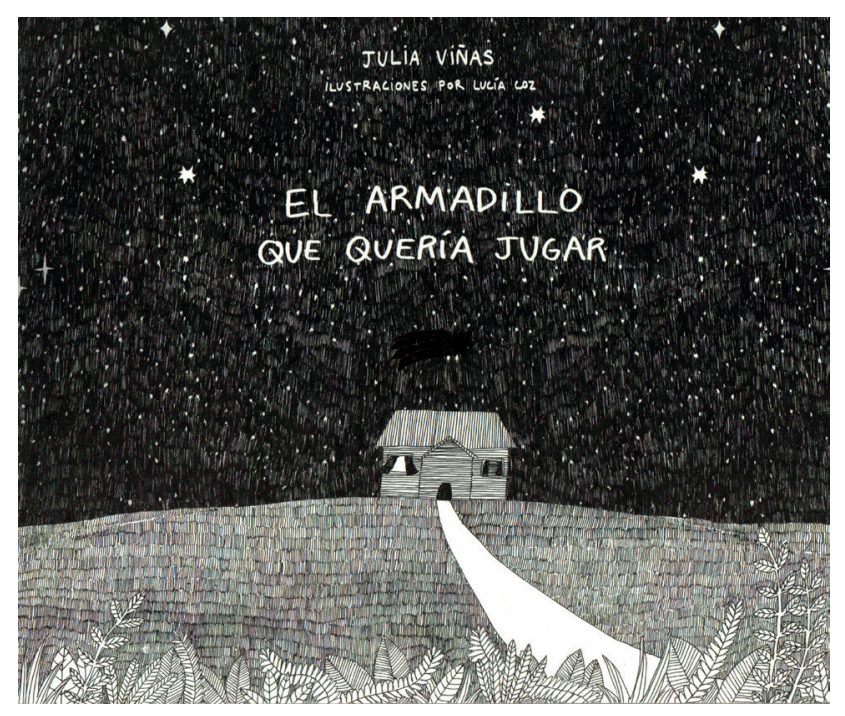

Cabe destacar que otras editoriales tradicionalmente dedicadas a la producción de literatura infantil y juvenil también apostaron por la publicación de libros álbum con ilustraciones de Christian Ayuni: ¡Silencio, Pollito!, con textos de Iván Herrera (Norma, 2017); El cerdito que no quería ser rosado, con textos de Isabel Menéndez (SM, 2017); y Luna Taricaya sale a pasear, con textos del ilustrador (Panamericana Editorial, 2018).

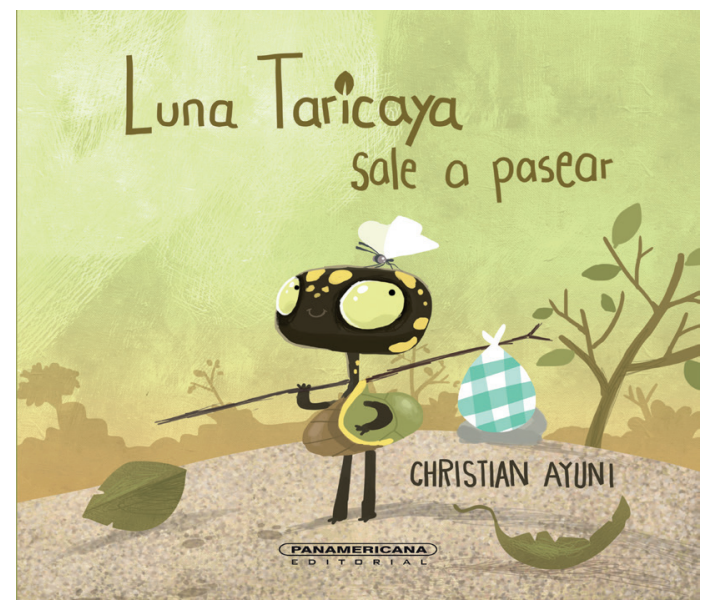


Por otro lado, este período significó la consolidación de autoras peruanas de libro álbum a nivel internacional gracias a importantes reconocimientos, a publicaciones con editoriales extranjeras de prestigio y la traducción de sus obras en diferentes lenguas, lo cual les ha permitido llegar a un público más amplio. Micaela Chirif publicó ¿Dónde está Tomás? (Ediciones Ekaré, 2016), con ilustraciones de Leire Salaberria (España). Este libro álbum obtuvo el Premio Cátedra Unesco de Lectura PUC-RIO 2019, una mención en la Medalla Colibrí 2017 y fue parte de la selección de la Fundación Cuatrogatos 2017 y de la selección bienal de Bratislava 2017. En el 2018, publicó Niebla (Amanuta), con ilustraciones de Carmen Cardemil (Chile); y Dentro de una cebra (Limonero), con ilustraciones de Renato Moriconi (Brasil). Este último fue seleccionado en el catálogo The White Ravens 2019.

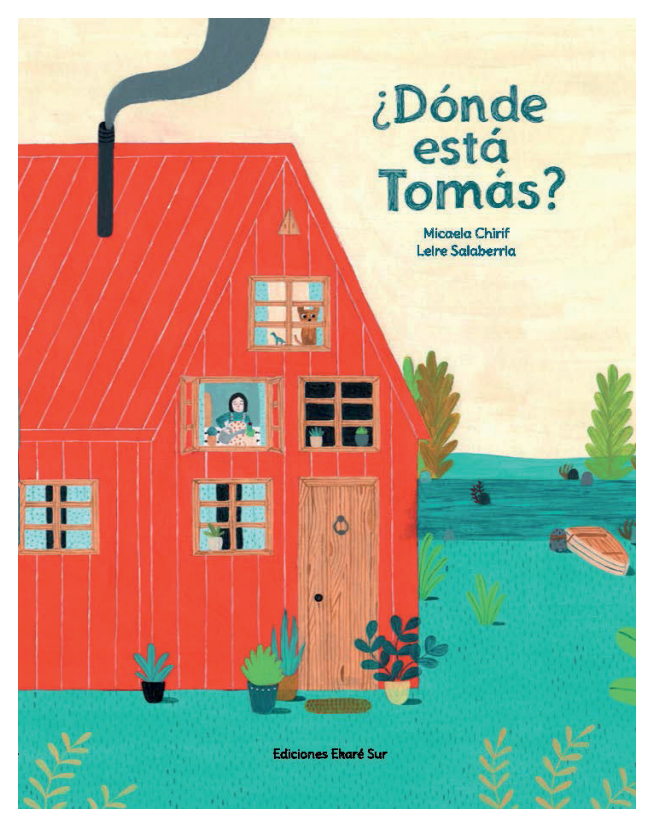

Asimismo, varios de los libros álbum con textos de Micaela Chirif fueron traducidos: ¿Dónde está Tomás?, al coreano y al portugués; Desayuno (con ilustraciones de Gabriel Alayza), al inglés y al portugués; y iMás te vale, mastodonte! (con ilustraciones de Issa Watanabe), al francés y al japonés.

Por su parte, Issa Watanabe fue seleccionada para la exposición de ilustradores de la Feria del Libro Infantil de Bolonia 2018 y 2020. Además, publicó Migrantes (Libros del Zorro Rojo, 2019), su primer libro álbum sin palabras que ha sido traducido al holandés, inglés, alemán, italiano, francés, esloveno y coreano. 


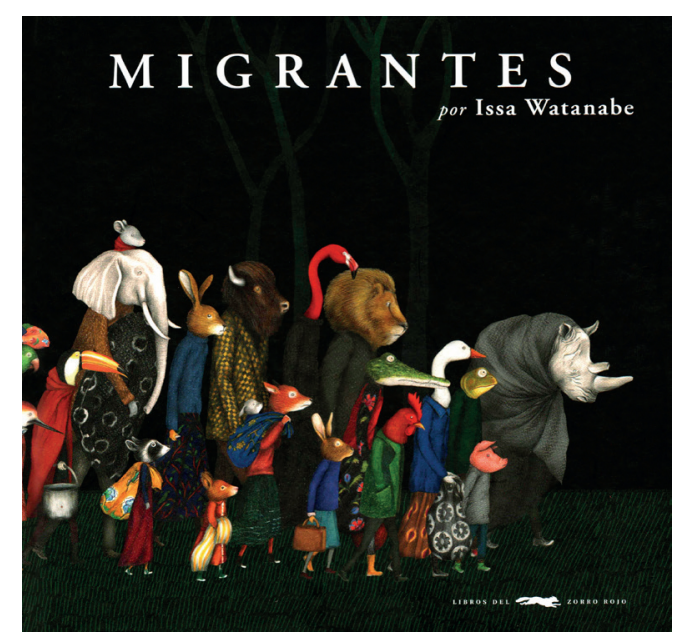

\section{REFERENCIAS}

Bosch, E. (2007). Hacia una definición del álbum. Anuario de Investigación en Literatura Infantil y Juvenil, 5, 25-46.

Colomer, T. (2010). Criterios de valoración y selección de libros infantiles y juveniles. En Introducción a la literatura infantil y juvenil actual (pp. 189-234). Madrid: Síntesis.

Consejo, E. (2014). El discurso peritextual en el libro ilustrado infantil y juvenil. Revista Álabe, 10, 1-17.

Eslava, J. (2009). Plan lector en la escuela peruana. Revisión de una política cultural y educativa. Universidad de Lima. Recuperado de http://www.ulima.edu.pe/ sites/default/files/research/files/charla_plan_lector_0.pdf

Peña, M. (2009). Perú, indigenismo y preocupación social. En Historia de la literatura infantil en América Latina (pp. 553-587). Madrid: Fundación SM.

Rodríguez, J. (2015). Panorama de la literatura infantil y juvenil en Perú (2013-2014). En Anuario iberoamericano sobre el libro infantil y juvenil 2015 (pp. 249-269). Madrid: Fundación SM.

Silva-Díaz, M. C. (2005). El álbum: tradición y postmodernidad. En Libros que enseñan a leer: álbumes metaficcionales y conocimiento literario (tesis doctoral, pp. 30-56). Universitat Autònoma de Barcelona.

Van der Linden, S. (2015). Álbum[es]. Barcelona: Ediciones Ekaré. 